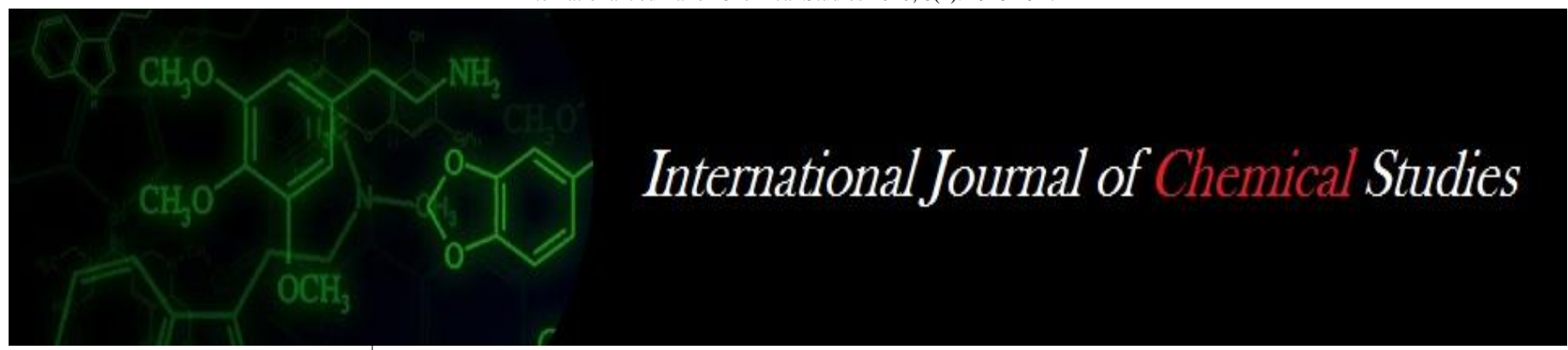

P-ISSN: 2349-8528

E-ISSN: 2321-4902

www.chemijournal.com

IJCS 2020; 8(2): 2915-2917

(C) 2020 IJCS

Received: 04-01-2020

Accepted: 06-02-2020

\section{Mina Koche}

Department of Plant Pathology, Shri. Shivaji Agriculture College, Amravati, Maharashtra, India

RM Gade

Associate Dean, College of

Agriculture, Gadchiroli,

Maharashtra, India

\section{RB Kothikar}

Junior Research Assistant, College of Agriculture, Nagpur, Maharashtra, India

Aparna Tekade

Student, PGI, Department of

Plant Pathology, Dr. PDKV,

Akola, Maharashtra, India

Corresponding Author:

Mina Koche

Department of Plant Pathology,

Shri. Shivaji Agriculture College,

Amravati, Maharashtra, India

\section{Biochemical studies on genotypic characterization of Pseudomonas fluorescens isolates by PCR- RAPD analysis}

\author{
Mina Koche, RM Gade, RB Kothikar and Aparna Tekade
}

DOI: https://doi.org/10.22271/chemi.2020.v8.i2as.9191

\begin{abstract}
Plant growth promoting rhizobacterial strains belonging to fluorescent Pseudomonads were isolated from the rhizosphere of citrus in Vidarbha region of Maharashtra, India. On the basis of morphological and biochemical studies, they were categorized as Pseudomonas fluorescens, $P$. putida and $P$. aurigonosa. Genotyping of these $P$. fluorescens strains was made by PCR-RAPD analysis since differentiation by biochemical methods was limited. Among the 16 primers screened, six primers (OPA-16, OPB-18, OPC15, OPC-19, OPG-05 and OPG-10) were polymorphic showed better amplification of DNA while other were recorded monomorphic. Similarity co-efficient between each pair of accessions was used to construct a dendrogram using the unweighted paired group method with arithemetic average (UPGMA).
\end{abstract}

Keywords: Pseudomonas fluorescens, PCR-RAPD, citrus, rhizosphere

\section{Introduction}

The diversity of Pseudomonads present in the soil also depends on the crop in the field and the type of metabolites that produce to arrest of the pathogens. Further differentiation within the same class of Pseudomonads based on the chemical component can be done with the help of molecular markers. Many molecular methods are used to detect the presence of soil-borne pathogens and also to assess the genetic variability among the different isolates (Kumar et al. 2002) [5]. Biological control of plant diseases using antagonistic microorganisms offers a highly effective, economical and environmental friendly alternative to the use of synthetic pesticides (Emmert, 1999) ${ }^{[1]}$. The mode of action of the antagonistic organisms against various soil-borne plant pathogenic fungi, include biosynthesis of antibiotics, production of hydrolytic enzymes (Velzahan et al. 1999) ${ }^{[15]}$, production siderophore and competition for substrates 2, 4-diacety phloroglucinol, which inhibits growth of pytopathogenic fungi (Thompson and Gould, 1994) ${ }^{[7]}$. Successful bacterial antagonists often show a synergistic combination of mechanisms responsible for a successful antifungal interaction. In the present investigation, 8 isolates from different location having citrus crop of research interest were genetically characterized using PCR based methods i.e. RAPD. The various isolates were grouped based on the polymorphic pattern obtained with these techniques.

\section{Materials and Methods}

Thirty soil samples collected from rhizosphere region of citrus in Vidarbha region using King's B medium (Kings et al. 1954) ${ }^{[4]}$. Colonies obtained on King'B medium were selected and further purified. They were subjected for differentiation and identification through different biochemical test viz., oxidase, catalase, arginine dihydrolysis, nitrate reduction, gelatine liquefaction and urease test. Based on bioefficacy studies the efficient strains were selected for PCR-RAPD analysis. The purpose of this study was to apply the RAPD technique for characterization of $P$. fluorescens and evaluate the ability of this technique to differentiate between them. A total of eight most efficient strains of $P$. fluorescens were used in this study. The DNA was extracted by the method of Kumar et al. (2002) ${ }^{[5]} .25 \mathrm{ml}$ actively grown $P$. fluorescens in nutrient broth culture was centrifuged in $30 \mathrm{ml}$ centrifuge tube at $6000 \mathrm{rpm}$ for 5 min at $4{ }^{\circ} \mathrm{C}$. The cell pellet was suspended in $1 \mathrm{ml}$ TE buffer and $0.5 \mathrm{ml} \mathrm{N}$ butanol. The suspension was centrifuged at $6000 \mathrm{rpm}$ for $5 \mathrm{~min}$ at $4{ }^{\circ} \mathrm{C}$ and discard the supernatant. The pellet was resuspended in $2 \mathrm{ml}$ of TE buffer and centrifuged at $6000 \mathrm{rpm}$ for $5 \mathrm{~min}$ at $4{ }^{\circ} \mathrm{C}$ to 
remove the traces of $\mathrm{N}$ butanol. The pellet was resuspunded in $1 \mathrm{ml}$ of TE buffer. $100 \mu \mathrm{l}$ of $10 \%$ SDS and $25 \mu \mathrm{l}$ of $100 \mu \mathrm{g} / \mathrm{ml}$ proteinase $\mathrm{K}$ were added, it was mixed well and incubated at $37^{\circ} \mathrm{C}$ for $1 \mathrm{~h}$. $200 \mu \mathrm{l}$ of $5 \mathrm{M} \mathrm{NaCl}$ and $150 \mu \mathrm{l}$ of CTAB $(10 \%$ stock) were added and mixed well and incubated at $4{ }^{\circ} \mathrm{C}$ for $10 \mathrm{~min}$. The cell lysate were deprotinized with $1 \mathrm{ml}$ Phenol: Chloroform mixture, mixed well and centrifuged at $6000 \mathrm{rpm}$ for $10 \mathrm{~min}$ at $4{ }^{\circ} \mathrm{C}$. The aqueous layer was carefully transferred to new $1.5-2 \mathrm{ml}$ microfuge tube and noted the volume. Ice cold isopropanol to the extent of $0.6 \%$ volume was added and incubated at $-20{ }^{\circ} \mathrm{C}$ for overnight. The suspension was centrifuged at $12000 \mathrm{rpm}$ for $15 \mathrm{~min}$ at $4{ }^{\circ} \mathrm{C}$. The supernatant was discarded. The pellet was dried and resuspended in $50 \mu \mathrm{l}$ of TE buffer and stored at $-20{ }^{\circ} \mathrm{C}$ for further use. The DNA concentration were determined spectrophotometrically at a wavelength of $260 \mathrm{~nm}$. Depending on the concentration of DNA determined, a stock solution with a concentration of $1 \mu \mathrm{g} / \mu \mathrm{l}$ was prepared for each isolate. PCR reactions were carried out in $20 \mu \mathrm{l}$ of reaction containing $10 \mathrm{X}$ PCR buffer $(2 \mu \mathrm{l}) ; 2.5 \mathrm{mM} \mathrm{MgCl} 2(1.5 \mu \mathrm{l}) ; 2 \mathrm{mM}$ of $\operatorname{dNTPs}(2 \mu \mathrm{l}) ; 2 \mu \mathrm{M}$ primer $(5 \mu \mathrm{l}) ; 1 \mu \mathrm{l}$ of Taq DNA polymerase $5 \mathrm{U}$; template DNA $(2 \mu \mathrm{l})$ and sterile water $(6.5$ $\mu 1)$. DNA samples were aplified on DNA thermocycler (Eppendorf, Germany) using the PCR conditions $94^{\circ} \mathrm{C}$ for 4 min, $94{ }^{\circ} \mathrm{C}$ for $30 \mathrm{sec}, 35^{\circ} \mathrm{C}$ for $30 \mathrm{sec}, 72^{\circ} \mathrm{C}$ for $1 \mathrm{~min}$. The total numbers of cycles were 40 , with the final extension time of $10 \mathrm{~min}$ at $72{ }^{\circ} \mathrm{C}$. The PCR products was electophorosed on $1.5 \%$ agarose gel run at constant voltage $70 \mathrm{~V}$ of $2 \mathrm{hrs}$ in $1 \mathrm{xTBE}$ buffer and stained with ethidium bromide solution $(0.5 \mu \mathrm{m} / \mathrm{ml})$. The DNA marker used was $10 \mathrm{kbp}$ ladder. The gels were photographed and analyzed using gel documentation system (Alpha Innotech Crop, USA). The bands which appeared consistently, were evaluated. The pair wise coefficient similarity based on the presence and absence of bands was calculated.

\section{Results and Discussion}

Thirty strains of $P$. fluorescens were isolated from soil samples of citrus collected from different region of Vidarbha, Maharashtra, India. All the fluorescent bacterial antagonists were gram negative, rod shaped and all produced yellowish green pigment on King's B medium. All were Oxidase and Arginine dihydrolase positive and were identified as $P$. fluorescens. Among the 30 isolates, 8 isolates of $P$. fluorescens were found to inhibit (13.55 - 38.88\%) the mycelial growth of Phytophthora (Table 1).

Table 1: Per cent growth inhibition of Phytophthora by $P$. fluorescens

\begin{tabular}{|c|c|c|c|}
\hline Sr. No. & Isolates & \% growth inhibition & Location \\
\hline 1 & $\mathrm{Pf}_{1}$ & 22.44 & Akola \\
\hline 2 & $\mathrm{Pf}_{6}$ & 13.55 & Akot \\
\hline 3 & $\mathrm{Pf}_{9}$ & 26.00 & Akoli Jahagir \\
\hline 4 & $\mathrm{Pf}_{14}$ & 24.33 & Warud \\
\hline 5 & $\mathrm{Pf}_{15}$ & 29.44 & Warud \\
\hline 6 & $\mathrm{Pf}_{18}$ & 15.77 & Amravati \\
\hline 7 & $\mathrm{Pf}_{19}$ & 26.22 & Katol \\
\hline 8 & $\mathrm{Pf}_{20}$ & 38.88 & Katol \\
\hline
\end{tabular}

In the present work a total 16 primers were used in RAPDs and 6 were found to be polymorphic (Table2). The amplified DNA fragments ranged from $9.00-0.30 \mathrm{kbp}$. The number of polymorphic loci amplified varied with different primers and isolates.
Table 2: List of primers screened against Pseudomonas fluorescens isolates

\begin{tabular}{|c|c|c|}
\hline Sr. No. & Primer Screened & Primers sequences \\
\hline 1 & OPA10 & GTGATCGCAG \\
\hline 2 & OPA12 & TCGGCGATAG \\
\hline 3 & OPA13 & CAGCACCCAC \\
\hline 4 & OPA14 & TCTGTGCTGG \\
\hline 5 & OPA15 & TTCCGAACCC \\
\hline 6 & OPA16 & AGCCAGCGAA \\
\hline 7 & OPB10 & CTGCTGGGAC \\
\hline 8 & OPB11 & GTAGACCCGT \\
\hline 9 & OPB14 & TCCGCTCTGG \\
\hline 10 & OPB15 & GGAGGGTGTT \\
\hline 11 & OPB18 & CCACAGCAGT \\
\hline 12 & OPC15 & GACGGATCAG \\
\hline 13 & OPC19 & GTTGCCAGCC \\
\hline 14 & OPC20 & ACTTCGCCAC \\
\hline 15 & OPG05 & CTGAGACGGA \\
\hline 16 & OPG10 & AGGGCCGTCT \\
\hline
\end{tabular}

All the bands were scored for their presence and absence in the 8 isolates and a similarity matrix was constructed using UPGMA program. Cluster analysis carried out based on the similarity data generated from the 8 isolates using 6 primers accounted for a total of 296 polymorphic DNA bands. The various $P$. fluorescens isolates were divided into two major classes (Fig. 1). Two of the isolates i.e. $\mathrm{Pf}_{15}$ and $\mathrm{Pf}_{14}$ formed one groups. Second class consisted of different subgroups with $\mathrm{Pf}_{9}, \mathrm{Pf}_{6}$ and $\mathrm{Pf}_{19}, \mathrm{Pf}_{18}$ and $\mathrm{Pf}_{20}$ and $\mathrm{Pf}_{1}$. The similarity among these isolates ranged from 0.158 to 0.044 . Genetic variability exists among the various isolates of Pseudomonads depending on the geographical locations from where these were collected, crops grown in a specific region and the agricultural practices employed in the location (Picard and Bosco, 2008) [9]. DNA-based (genotypic) approaches (Saharan and Naef 2008; Schutte et al. 2008) ${ }^{[13,14]}$ have increasingly been applied to microbial identification and classification. In fact, these molecular approaches have resulted in the birth of a new ecology subspecialty. Generally, these methods tend to be dependent on bacterial growth variables, more stable, less time-consuming and are very useful for determining phylogenetic relationship among microbial isolates and for assigning strains into specific groups. The similarity data obtained with RAPD primers identified 2 major groups by cluster analysis. The grouping does not appear to be based on geographic origin as $\mathrm{Pf}_{14}$ and $\mathrm{Pf}_{15}$ were from the same location but not from the same field. The genotypic and phenotypic diversity of $P$. fluorescens could be based on the geographic origin or functional differences in the genome of the strains (Naik et al. 2008) ${ }^{[6]}$.

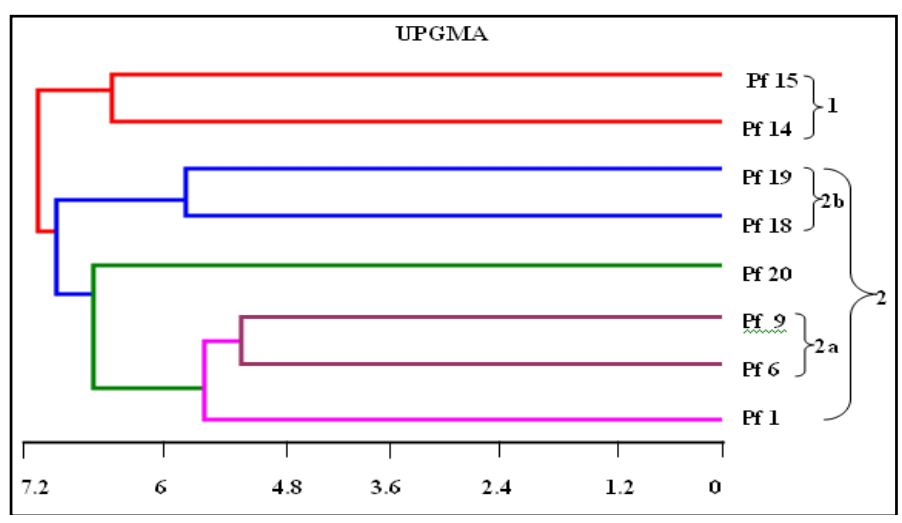

Fig 1: Phylogenic tree of 8 Pseudomonas fluorescens isolates obtained by UPGMA, distance coefficient on the basis of RAPD 
RAPDs are able to differentiate a large number of isolates unique bands that can be used for fingerprinting and protecting commercial $P$. fluorescens isolates. It is important to combine molecular diversity with the antibiotic-producing property of the isolates to properly identify the different strains prevalent in crop fields. Sabir et al. (2013) ${ }^{[11]}$ worked on the electrophoretic analysis of RAPD band profiles of Bacillus thuringiensis and observed the presence of polymorphism among the studied isolates. Pethannan et al. (2018) ${ }^{[8]}$ isolated $P$. aeruginosa from various clinical samples and evaluated for their variability and genetic relationship using PCR based Randomly Amplified Polymorphic DNA (RAPD) technique. Further genetic relationship was determined using RAPD technique. A total of 7 were isolated and characterized biochemically and identified belonging to $P$. aeruginosa. Cluster analysis and phylogenetic tree reveal close relatedness between $P$. aeruginosa strain P1, P3, P4, P5 and P6 but distantly related to the P2 and P7. Molecular methods help to identify novel strains of Pseudomonads which will be more effective as biocontrol agents in a particular region. It is important to correlate molecular diversity with functional diversity to assess the utility of these isolates as biocontrol agents for a particular crop in local fields which can then be extrapolated to the same crop in other fields or even other crop.

\section{References}

1. Emmert EAB, Handelsman J. Biocontrol of plant disease: a (Gram) positive perspective. FEMS Microbiology Letters. 1999: 171:1-9.

2. Hass D, Keel C. Regulation of antibiotic production in root-colonizing Pseudomonas spp. and relevance for biological control of plant disease. Annual Review of Phytopathology. 2003. 41:117-153.

3. Keel C, Weller DM, Natsch A, Defago G, Cook RJ, Thomashow LS. Conservation of the 2,4diacetylphoroglucinol biosynthesis locus among fluorescent Pseudomonas strains from diverse geographic locations. Applied and Environmental Microbiology. 1996; 62:552-563.

4. King EO, Ward MK, Raney DE. Two simple media for the demonstration of pyocenin and fluorescin. J Lab. Clin. Med. 1954; 44:301-307.

5. Kumar NR, Thirumalai V, Arasu, Gunasekaran P. Genotyping of antifungal compounds producing plant growth promoting rhizobacteria and Pseudomonas fluorescens. Current Science. 2002; 82(12):1463-1466.

6. Naik PR, Raman G, Narayanan KB, Sakthivel N. Assessment of genetic and functional diversity of phosphate-solubilizing fluorescent Pseudomonads isolated from rhizospheric soil. BMC Microbiology. 2008; 8:230-235.

7. Thompson Nowak and Steven Gould. Production of 2,4diacetylphloroglucinol by the biocontrol agent Pseudomonas fluorescens pf- 5. Can. J. Microbiol. 1994. 40:1064-1066.

8. Pethannan R, Amudha C, Kuppuswamy, Rajani Gupta, Kumar KV, Swati Baliyan G et al. RAPD characterization of Pseudomonas species identified from clinical samples. Recent Res. Sci. \& Techno. 2018; 10:11-15.

9. Pieard C, Bosco M. Genotypic and phenotypic diversity in populations of plant-probiotic Pseudomonas spp. colonizing roots. Naturwissenschaften. 2008; 95:1-16.
10. Rabindran R, Vidhyasekaran P. Development of a formulatin of Pseudomonas fluorescens Pf ALR2 for management of rice sheath blight. Crop Protection. 1996; 15:715-721.

11. Sabir JS, Salah Said AA, Hussein MM, Rayah Al-Saud, Mutwakil Mohammed N. Isolation, identification and RAPD-PCR analysis of new isolated Bacillus thuringensis. Life Science J. 2013; 10:1352-1361.

12. Samantha SK, Dutta S. Potential of native plant growth promoting rhizobacteria in the management of Sclerotina stem rot of mustard. J Mycol Pl Pathol. 2004; 34: 761768.

13. Saharan MS, Naef A. Detection of genetic variation among Indian wheat head scab pathogens (Fusarium spp. isolates) with microsatellite markers. Crop Protection. 2008; 27:1148-1154

14. Schutte UME, Abdo Z, Bent SJ, Shyu C, Williams CJ, Pierson JD, Forney IJ. Advances in the use of terminal restriction fragment length polymorphism (t-RFLP) analysis of $16 \mathrm{~S}$ rRNA genes to characterize microbial communities. Applied Microbial Biotechnology. 2008. 80:365-380.

15. Velzahan R, Samiyappan R, Vidyasekaran $P$. Relationship between antagonistic activities of $P$. fluorescens isolates against $R$. solani and their production of lytic enzymes. J Pl Dis. Protec. 1999. 106:244-250 